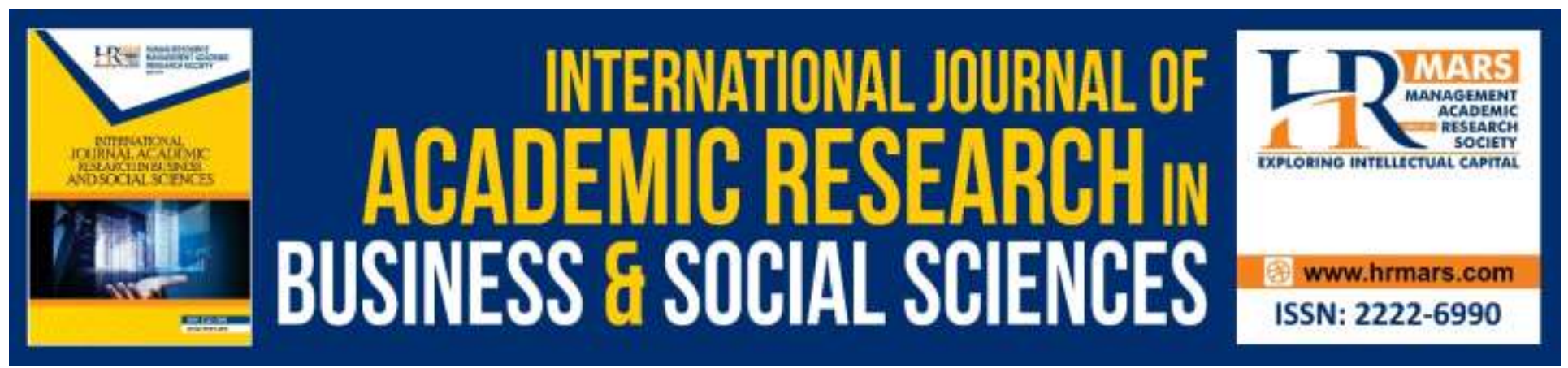

\title{
Organizational Management, in the Context of Change Management and Performance of Companies Listed in Nairobi Securities Exchange in Kenya
}

Aketch Ng'ong'a, Leon Awiti, Richard M. Imbambi, Wycliffe Mande

To Link this Article: http://dx.doi.org/10.6007/IJARBSS/v10-i2/6921

DOI:10.6007/IJARBSS/v10-i2/6921

Received: 20 December 2019, Revised: 10 January 2020, Accepted: 30 January 2020

Published Online: 03 February 2020

In-Text Citation: (Ng'ong'a et al., 2020)

To Cite this Article: Ng'ong'a, A., Awiti, L., Imbambi, R. M., \& Mande, W. (2020). Organizational Management, in the context of Change Management and Performance of Companies Listed in Nairobi Securities Exchange in Kenya. International Journal of Academic Research in Business and Social Sciences, 10(2), 212-235.

Copyright: (C) 2020 The Author(s)

Published by Human Resource Management Academic Research Society (www.hrmars.com)

This article is published under the Creative Commons Attribution (CC BY 4.0) license. Anyone may reproduce, distribute, translate and create derivative works of this article (for both commercial and non-commercial purposes), subject to full attribution to the original publication and authors. The full terms of this license may be seen at: http://creativecommons.org/licences/by/4.0/legalcode

Vol. 10, No. 2, 2020, Pg. 212 - 235

http://hrmars.com/index.php/pages/detail/IJARBSS

JOURNAL HOMEPAGE

Full Terms \& Conditions of access and use can be found at http://hrmars.com/index.php/pages/detail/publication-ethics 


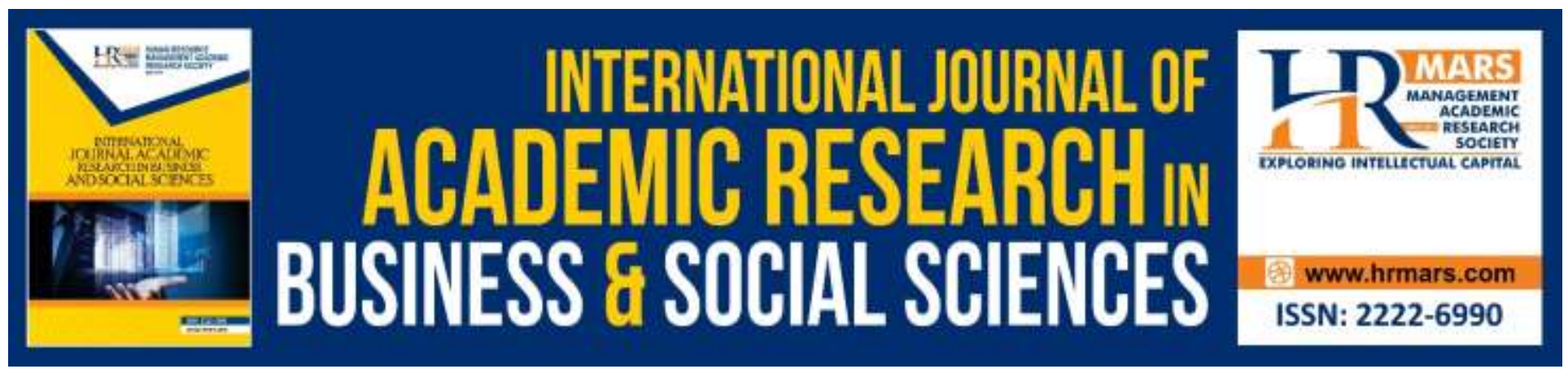

\title{
Organizational Management, in the context of Change Management and Performance of Companies Listed in Nairobi Securities Exchange in Kenya
}

\author{
Aketch Ng'ong'a, PhD \\ Email: aketchngonga@yahoo.com \\ Leon Awiti, $\mathrm{PhD}$ \\ Monitoring, Research, Evaluation and Learning Practitioner, Kenya \\ Email: awitileon@gmail.com \\ Richard M. Imbambi, PhD \\ Email: rmimbambi@yahoo.com \\ Wycliffe Mande \\ Human Resource, Research and Learning Practitioner, Kenya \\ Email: cliffmande@yahoo.com
}

\begin{abstract}
Companies are faced with turbulent and chaotic business environment which has a significant effect on organizational performance. Notably, majority of organizations are unable to effectively manage operations/processes in the face of the changing organizational management, which has had an impact on their competitiveness. In Kenya, there are a number of companies that have either collapsed or stagnated as a result of their inability to manage change and adopt a suitable organizational management effectively. The purpose of this study was to establish the effect of organizational management, in the context of change management and performance of companies listed in NSE in Kenya. The theories that underpinned the study were; three-step change theory, open systems theory and industrial organization economics theory. The study objectives sought to assess the effect of organizational management on performance of companies listed in NSE. A cross sectional survey design was used on 64 companies listed in the NSE in Kenya. The sample size was 38 companies from (2013-2017) as at 30th June, 2017. Purposive sampling technique for 4 senior managers namely, Chief Executive Officers, divisional heads in Human Resource, Finance and Marketing in the listed companies in NSE were targeted with a sample size of 152 managers. Pilot study was conducted on 15 respondents and reliability coefficient $(r)$ was above the recommended threshold of 0.7.The study used five point Likert Scale to measure change management and
\end{abstract}


INTERNATIONAL JOURNAL OF ACADEMIC RESEARCH IN BUSINESS AND SOCIAL SCIENCES Vol. 10, No. 2, Feb, 2020, E-ISSN: 2222-6990 @ 2020 HRMARS

performance. Secondary data was obtained from published sources and primary data from the semistructured questionnaire. The analysis comprised descriptive statistics, Pearson's correlation, hypotheses testing and regression analysis using ANOVA Descriptive statistics analysis assessed that there was a positive effect of organizational management on performance of companies listed in NSE to a large extent. There was a significant moderate positive correlation between organizational management and performance of companies. The null hypothesis was rejected and the alternative hypothesis was adopted. The regression showed that there was a significant positive relationship between organizational management and performance of companies. The study concluded that there was an effect of organizational management, in the context of change management and performance of companies listed in NSE. The study recommended that managers should get recent and relevant information that exists to ensure that wastage of resources is minimized. Further studies may re-look at the role of both middle and lower level employees as regards organizational management in the organization.

Keywords: Organizational Management, Change Management, Performance of Companies, Nairobi Securities Exchange (NSE)

\section{Background of the Study}

Change management presents organizations with a competitive edge over other players in the industry in a dynamic competitive environment. The increasing global competition, technological change and expansion of customer expectations are creating turbulent competitive environment for organizations to be competitive (Khatoon \& Farooq, 2016). Burnes (2004) observed that Lewin's experiments on planned change started during the World War II in an effort to change consumer behavior. In the late nineteenth century the complexity to change management started in United States of America (Swarnalatha \& Prasanna, 2013). In Australia, change management both at federal and state level showed a sense of urgency for the government to revitalize public service that was able to sustain continuity and change (D'Ortenzio, 2012). Strategic change is a way of changing the objectives and vision of the company in order to obtain greater success (Naghibi \& Baban, 2011). Organizational change is a complex activity that any tiny mistake in change management could lead to failure of organizational change (Song, 2009). Saif, Razzaq, Rehman, Javed \& Ahmad (2013) noted that organizations that are most likely to be successful in making change work view change as a constant opportunity to evolve the business.

According to Kamugisha (2013) change can originate from external forces through technological advances, social-political or economic pressures or it can come from inside the organization. Boohene \& Williams (2012) opined that employees often resist change efforts if they are not involved. Rezvani, Dehkordi \& Shamsollahi (2012) noted that organizational change is the procedure by which the organization moves from its current position and state towards some future position that has a competitive edge. Hutter (2006) argued that change is understood as a sequence of events. Suresh (2011) defines change management as a method of empowering organizations and individuals for taking over their responsibility. Aljohani (2016) defines change management as a "set of aptitudes and skills an individual is required for successful initiation and implementation of change in creation of value for the organization." D'Ortenzio (2012) noted that organizations must realize that it is important to have an integrated approach to any change program that involves combining structural, technological and behavioral approaches. Victor \& Franckeiss (2002) argued that organizational 
INTERNATIONAL JOURNAL OF ACADEMIC RESEARCH IN BUSINESS AND SOCIAL SCIENCES Vol. 10, No. 2, Feb, 2020, E-ISSN: 2222-6990 @ 2020 HRMARS

change needs to focus on developing strategy through to operational implementation and evaluation. Concrete purposes of change management for different organizations are probably not the same though it makes organizations more effective, efficient and responsive to the turbulent competitive environmental changes (Song, 2009).

Terry (1977) refers to management as a distinct process consisting of planning, organizing, motivating and controlling what is performed to determine and accomplish stated objective by the use of human beings and other resources. Ufartiene (2014) describes planning process as one of organization's management functions and core function of organization management. During planning process, managers should be able to evaluate all potential tasks and pick the most important ones. Vanagas \& Stankevic (2014) refers to coordination of change process as an establishment of communication channels between people who are executing different work that is intended to correct the executor's actions, that does not comply with selected course of the plan. Abbah (2014) refers to motivation of staff as providing leadership for subordinates and requires the ability to inspire them to put in their efforts in achieving the organizations objectives, by creating good moral or working spirit among employees. And that what motivates one person might not motivate another and therefore, for the best results any manager should understand and as far as feasible, get to know something about each of his/her subordinates (Abbah, 2014). Nurwati (2013) refers to control function (controlling) as a role to detect potential weaknesses that occur as a feedback to the management of an activity, starting from the planning stage to the implementation stage. Controlling of resources function includes the creation of standards or criteria, comparing results with standard monitoring, the implementation of an improvement over the deviation or aberration, modification and adjustment of the changing conditions, as well as communicating the revisions and adjustments of process management so that irregularities or flaws are not repeated again (Nurwati, 2013).

Olusanya, Awotunggase \& Ohadebere (2012) indicated that planning involves selecting from among alternative future course of action for the organization as a whole in every department or section. Whereas, Kabiru, Theuri \& Misiko (2018) stated that in business, strategic planning offers complete direction for specific units such as human resources, financial focuses and marketing. Kabiru, Theuri \& Misiko (2018) further indicated that without a vision, good plan or strategy the performance of a project would fail. Abiro (2013) opined that motivation helps propel employees in an organization towards a good directed pattern to achieve the organizational objectives. Motivation should be directed towards improving company operations. Whereas, Gitahi \& K'obonyo (2018) indicated that the company controls the internal factors and ensures that the resources are used responsibly so long as the management plans, organizes, leads and controls resources effectively.

According to Gaye (2017) stated that the performance of Kenyan economy grew steadily at an average rate of $5 \%$ per year with the exception of 2017 where it grew by $4.7 \%$. The GDP growth of $5.7 \%$ in $2015,5.9 \%$ in 2016 and $4.9 \%$ in 2017 . The GDP in agriculture was (24.2\%), industry (14.8\%), services (62.5\%) in 2015 (Gaye, 2017).The performance indicated that there was a decline of 1\% between 2016 and 2017 GDP growth rate (Gaye, 2017). The GDP by services was relatively higher than agriculture and industry by $38.3 \%$ and $47.7 \%$ respectively. Gaye (2017) recommended that credit access can be supported by reducing public borrowing and the transactions cost for accessing credit through reporting, creation of a central electronic collateral registry and a framework to promote property as collateral with the automation of land registries and implementation of National Payments Systems Act (Gaye,2017). 
INTERNATIONAL JOURNAL OF ACADEMIC RESEARCH IN BUSINESS AND SOCIAL SCIENCES Vol. 10, No. 2, Feb, 2020, E-ISSN: 2222-6990 @ 2020 HRMARS

Lewis's three step model analyses brings about planned change at group, organizational and societal levels (Burnes, 2004). Chaos and complexity theory accounts for dynamic evolution of industries and complex interactions among industry actors (Levy, 1994). And lastly, the industrial organization economics theory was used to analyze business strategy that is anchored on organizational performance (Suresh, 2011). Capital Markets Authority and Nairobi Securities Exchange being regulatory bodies have an obligation to ensure that listed companies comply and operate according to the set down standards when trading in the securities exchange (CMA, 2002; NSE, 2013). The financial reports on performance of public listed companies are shared with these regulatory bodies, investors and the public to ensure that there is an element of transparency (NSE, 2014). They reflect the company's profitability at the end of a financial year. In this study the variables that were discussed include; organizational management to address change management and performance of companies listed in NSE in Kenya.

\section{Statement of the Problem}

Globally, companies are faced with rapidly changing business environment which significantly affect organizational performance. In Kenya, there are a number of companies that have either collapsed or stagnated as a result of their inability to manage change effectively. Managers should get recent and relevant information that exists on organizational management to ensure that wastage of resources is minimized and manage change to be competitive and survive in the changing business environment. Nohria \& Beer (2000) observed that about $70 \%$ of all change initiatives fail. The challenge is how to make large corporations implement change management to realize better and superior financial performance with a robust and flexible organizational management.

Capital Markets Authority (CMA) approves public offers and listings of securities traded at NSE in Kenya (CMA, 2002). Statistics available indicate poor financial performance trend of companies listed in NSE that include; Kenya Airways which reported a loss of 10 billion (CMA, 2013) and their rationalization of operations resulted in a decline in direct operating cost by ksh.2.5 billion to 65.2 billion by the end of March 2016 financial year (NSE,2016). Mumias Sugar Company Limited reported a loss of Sh.4.7 billion by the end of June 30,2016 financial year, compared to Sh.4.6 billion the previous fiscal year 2015 and compared to ksh.4.6 billion the previous fiscal year (NSE, 2016). Uchumi Supermarkets posted a loss of Sh.2.8 billion by over half a billion shillings less than its previous fiscal year 2015 (NSE, 2016). Eveready East Africa limited lost 248 million and is already existing Kenya Markets (CMA, 2013). NSE suspended CMC Holdings limited and later delisted it for malpractices among others. These companies were suspended from trading in NSE due to poor financial performance which was attributed to poor organizational management. Their financial reporting did not reflect the true financial status due to corruption, frauds, scandals, improper control systems and ineffective regulations.

Beshtawi \& Jaaron (2014) study on change management in telecommunication sector in Palestine of forty-two semi-structured interviews among 23 managers and supervisors; and 19 line employees did not use combine non-financial and financial indicators on performance. By (2005) study was a critical review of theories and approaches to organizational change management but not empirical test. Irungu (2007) conducted a study on the effect of top management teams on performance of publicly quoted companies in Kenya was longitudinal survey of 47 companies in NSE in Kenya from 2001-2005. Machuki (2011) conducted a study on external environment-strategy co-alignment, firm 
INTERNATIONAL JOURNAL OF ACADEMIC RESEARCH IN BUSINESS AND SOCIAL SCIENCES

Vol. 10, No. 2, Feb, 2020, E-ISSN: 2222-6990 @ 2020 HRMARS

level institutions and performance of public quoted companies in Kenya was longitudinal survey of 53 companies from 2005-2009. The methodology used in this current study was sampling technique for 38 companies from 2013-2017. There is no study which has been undertaken on organizational management, in the context of change management and performance of companies listed in NSE in Kenya which this study addressed.

\section{Research Objective}

To assess the effect of organizational management on performance of companies listed in NSE.

\section{Research Hypothesis}

$\mathrm{H}_{0}$ : Organizational management does not significantly affect performance of companies listed in NSE.

\section{Theoretical Framework}

This study was guided by change management theories namely, the three step change theory was propounded by Lewin (1951) to provide a high-level approach to change by giving a manager or other change agent a framework to implement a change effort, which is always very sensitive and must be made as seamless as possible. Chaos and complexity theory was pioneered by Lorenz (1963) in studying dynamics of turbulent flow in fluids. Industrial organization economics was propounded by Bain (1968) for an analytical framework to make relations amongst market structure, market conduct and market performance that will determine its conduct and performance.

\section{The Three Step Change Theory}

The theory of change was propounded by Lewin (1951) and it looked at change in a three step model of unfreezing, moving and refreezing. Lewin conceived the three-step model in analyzing, understanding and bringing about planned change in groups, organizational and societal level. The first step was unfreezing, which means that human behavior was based on a quasi-stationery equilibrium supported by a complex field force. Before old behavior could be discarded (unlearnt) and new behavior successfully adopted, the equilibrium needed to be destabilized (unfrozen) (Burnes, 2004). The second step was moving, that meant taking into consideration all the operating forces, identifying and evaluating iteratively the available options.

Whereas, the third step was refreezing, that meant to stabilize the group at a new semi- stationary balance that would ensure that new practices were relatively safe from regression. The new behavior must be, to some degree, congruent with the rest of the behavior, personality and environment of the learner or it would simply lead to a new round of disconfirmation (Schein, 1996). Refreezing were those change processes in organizational culture, norms, policies and practices which the organization is undertaking during change process (Burnes, 2004). Lewin's model does not explicitly state the notion that simply introduces change that results in adoption or sustenance for long. Lewin's planned change approach is still very relevant globally (Burnes, 2004).

McAleese, Creed \& Zutshi (2013) assert that new procedures and practices was uncomfortable for manager's implementation due to internal and external resistance. Organizations are now moving from planned change approach to emergent strategy development and this requires an organizational culture that will open and flexible (McAleese, Creed \& Zutshi, 2013). Other theories 
INTERNATIONAL JOURNAL OF ACADEMIC RESEARCH IN BUSINESS AND SOCIAL SCIENCES Vol. 10, No. 2, Feb, 2020, E-ISSN: 2222-6990 @ 2020 HRMARS

include, Prochaska \& DiClemente's (1983) propounded change theory that focused on concentrated on precontemption, contemplation, preparation, action and support. Social Cognitive Theory was propounded by Bandura (1986) focused on behavior change that is affected by environmental influences, personal factors and attributes of behavior itself. Theory of Reasoned Action and Planned Behavior was propounded by Fishbein et al. (1992) that focused on individual's attitude towards the desired behavior that is positive for change to occur by influencing a person's social environment or subjective norm (Kritsonis, 2005). The three step change theory informed the variable of change management in the study.

\section{Open Systems Theory}

This was propounded by Bertalanffy (1968) and argued that traditional closed system models based on classical science and the second law of thermodynamics was inadequate for explaining large classes of phenomena. Bertalanffy (1968) maintained that the conventional formulations of physics are in principle, inapplicable to the living organism being open systems having steady state. The open systems theory states that large organizations has multiple subsystems that receives inputs from subsystems and turns them into outputs for use.

According to Basted (2004) organizations are open systems that conduct business and realign according to the changing external environment that occur in both local and global front. The parts that make up the organization are interrelated and are contingent on subsystem functioning. Open systems import and export material from and to the environment (Bruce, 2010). Hanna (1988) indicated that open systems theory was a comprehensive model that described parts of an organization and how they relate to one another. Pasmore \& Sherwood (1978) argued that systems thinking provide guidance and direction for exploration of an organization and its goals for change. And that it describes the complex relationships between people, tasks, technologies and helps us to see how these can promote organizational performance (Pasmore \& Sherwood, 1978).

Other theories include, Administrative Theory was propounded by Fayol (1949) focused on the utilization of a formalized administrative structure, division of labor and delegation of power and authority to administrators. Scientific Management Theory was propounded by Taylor (1911) focused on most efficient way of managing and making the workers more productive. However, the theory informed the variables/concept of organizational management in the study.

\section{Industrial Organization Economics Theory}

This was propounded by Bain (1968) and focused on the experience of industrialized nations (Basu, 1993). The field of industrial organization had been transformed during the past twenty years and that game theory had emerged as a predominant methodology for analyzing business strategy (Shapiro, 1989). This means that the new industrial organization involves specifying a game among competing firms and solving that game in extensive form using the non-cooperative solution concept of Nash equilibrium or one of its refinements. Using extensive form games to model strategic interactions has the virtue of forcing the analyst to think carefully and to be quite precise about specific nature of competition. At this time game theory provides the only coherent way of logically analyzing strategic behavior (Shapiro, 1989).

Fisher (1989) argued that game theoretic approach to industrial organization had been unsuccessful. The sensitivity of equilibrium behavior had evidence that the game theoretic approach had failed 
since the specification may be hard to discern from available industry information. Whereas, Shapiro (1989) further reported that game theory indicates about the conditions that different outcomes take place and the factors which are most critical in shaping behavior and performance in concentrated industries.

According to Porter (1981) the traditional brain/mason paradigm of industrial organization offered strategic management a systematic model for assessing competition within an industry, yet the model was seldom used in the business policy field. Industrial organization and business policy differed in their frame of reference (public vs. private), units of analysis (industry vs. firm), views of the decision maker and stability of structure and in other significant respects. Porter (1981) concluded that the development of industrial organization theory during the 1970's had indicated that the industrial organization should be resourceful to policy scholars.

Other theories include, Stakeholders Theory propounded by Freeman (1984) focused on defined objectives for what each stakeholder group expects from the corporation and how each group contributes to the success of the corporation. Balance Scorecard Theory was propounded by Norton \& Kalpan (1992) and focused on non-financial and financial measures of monitoring performance. However, Industrial organizational Economics Theory informed the variable/concept of performance of companies in this study.

\section{Conceptual Framework}

This study was guided by the following conceptual framework. This is presented in Figure 1.

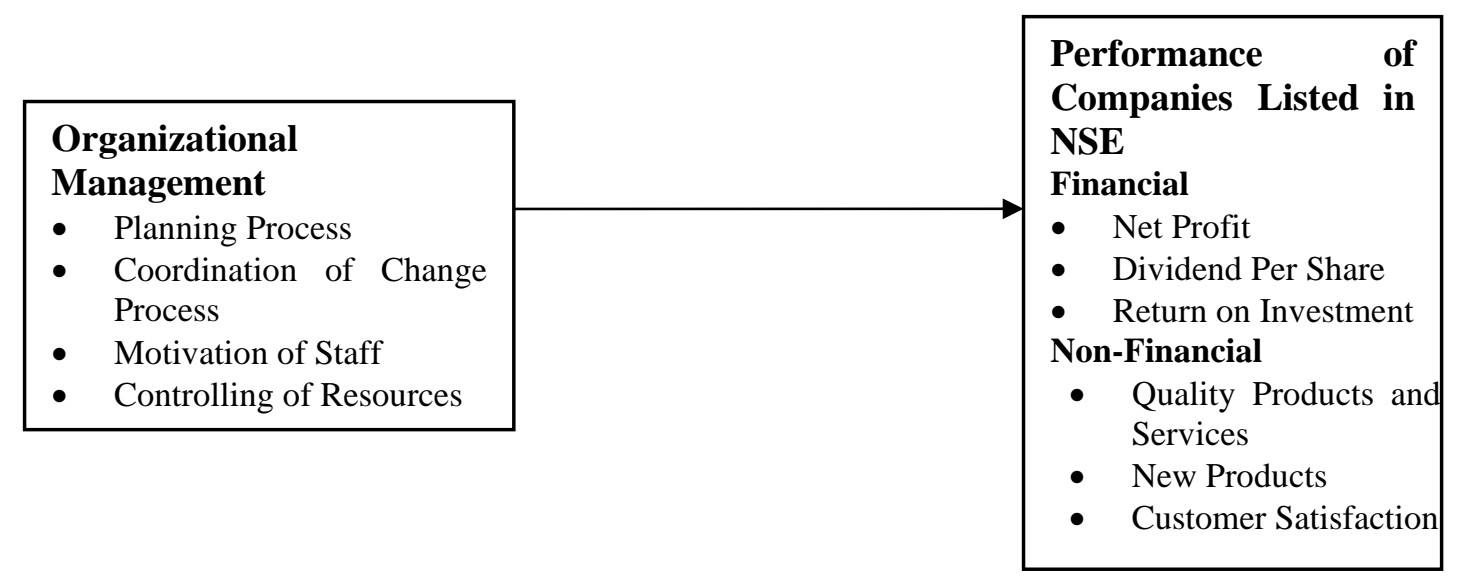

Figure 1: Conceptual Framework of the Study

Organizational management was presumed to affect performance of companies listed in NSE and was presented on the left-hand side of the diagram in figure 1 as independent variable and performance of companies was the dependent variable and was presented on the right-hand side of the conceptual framework.

\section{Empirical Review of the Study Variables}

Muogbo (2013) conducted a study on strategic management, organizational growth and development of selected manufacturing firms in Anambra State, Nigeria. Muogbo reported that strategic management adoption had an effect on employee's performance by increasing 
INTERNATIONAL JOURNAL OF ACADEMIC RESEARCH IN BUSINESS AND SOCIAL SCIENCES Vol. 10, No. 2, Feb, 2020, E-ISSN: 2222-6990 @ 2020 HRMARS

organizational productivity and enhancing structural development of manufacturing firms. The target population was 63 respondents selected from 21 manufacturing firms with a sample of 3 firms each. Descriptive statistics and chi-square was used. The study concluded that strategic management was not yet a common business practice among manufacturing firms but an important tool for improving the competitiveness, performance levels and structural development of manufacturing firms in Nigeria. Muogbo (2013) recommended that entrepreneurial center and business schools in Nigeria should incorporate strategic management principles into their curricula and further studies should be carried out to investigate the causes on non-adoption of strategic management. This study did not consider organizational management variable and indicators such as planning process, coordination of change process, motivation of staff and controlling of resources. Muogbo (2013 study concentrated on manufacturing firms in Anambra State and failed to address different sectors, a gap this study intends to address in the Kenyan context.

In another study by Kehinde (2012) on the effect of talent management and organizational performance in Nigeria reported a positive impact of organizations overall performance in the multinational and national firms. They further reported that small and medium scale firms had not gained from the new technique within the Nigerian business environment. Sixteen copies of the questionnaire were administered randomly to the senior managers (CEO's or director) for collecting primary data. Bi-variate correlation and statistical package for social sciences (SPSS version 17) was employed in computing the Pearson's correlation coefficients, t-statistic was employed to test the hypotheses formulated in the study and the descriptive analyses were used to analyze data. Kehinde (2012 recommended that talent management scheme should be used for all categories of staff within the firm that had special talent and that firms should separate between their talent management scheme and the total human resources management style of the firm. The study did not consider organizational management variable and indicators such as coordination of change process, motivation of staff and controlling of resources, even though planning process was considered as being a tool in talent management for human resource management. Kehinde (2012 study had 16 respondents which was a small sample size for generalization of results of the study, a gap which this study intends to fill.

A study by Aremu \& Oyinloye (2014) on the relationship between strategic management and firm's performance on selected banks, llorin Metropolis in Kwara State, Nigeria reported that strategic management affected organizational performance. They further reported that no matter how wellstructured and organized a plan may be, if not implemented, business failure was inevitable. A research survey and a random selection of five banks was used in the study. Primary data was collected from 100 questionnaires. Statistical techniques and hypothesis was tested using t-test. Multiple regression analysis with the aid of statistical package for social science (SPSS) was used. Aremu \& Oyinloye (2014) recommended that the process of strategic management must be carefully implemented for an organization to be outstanding in its performance and have competitive advantage and stay afloat in the dynamic environment. The study did not consider organizational management variable and indicators such as coordination of change process, motivation of staff and controlling of resources. Aremu and Oyinloye (2014) study concentrated on five banks in Kwara State in Nigeria and failed to address different sectors of the economy, a gap which the study intends to address in the Kenyan context. 
INTERNATIONAL JOURNAL OF ACADEMIC RESEARCH IN BUSINESS AND SOCIAL SCIENCES Vol. 10, No. 2, Feb, 2020, E-ISSN: 2222-6990 @ 2020 HRMARS

\section{Performance of Companies listed in NSE}

Santos \& Brito (2012) conducted a study toward a subjective measurement model for firm performance and reported that dimensions cannot be used interchangeably because they represent different aspects of firm performance and that stakeholders also have different needs. Their study used confirmatory factor analyses data from 116 Brazilian senior managers to test its fit and psychometric properties. Santos \& Brito (2012) study lacked convenience and geographic characteristics of the sample to allow generalization of the results and failed to test the market value. The final model had six first order dimensions: profitability, growth, customer satisfaction, employee satisfaction, social performance, and environmental performance. A second-order financial performance construct, influencing growth and profitability, correlated with the first-order inter correlated, non-financial dimensions. They recommended that researchers and practitioners may use the model to fully treat performance in empirical studies and to understand the impact of strategies on multiple performance facets.

Another study by Fauzi, Svensson \& Rahman (2010) reviewed corporate, financial and social performance. They reported that the concept of triple bottom line as sustainable corporate performance should consist of three measurement elements namely; (i) financial, (ii) social and (iii) environmental. The content of each of these measurement elements may vary across contexts and over time and they should be interpreted to be a relative concept that is dynamic and iterative. They recommended that continuous monitoring need to be performed, adapting the content of the measurement elements to changes that evolve across contexts and over time in the marketplace and society. Kabajeh, Nu'aimat \& Dahmash (2012) study examined ROA, ROE and ROI ratios together and separately with Jordanian insurance public companies share prices during the period (2002-2007). They reported that there was a positive relationship between ROA, ROE, ROI ratios and Jordanian insurance public companies share prices. Their findings further showed a positive but low relationship between each of ROA ratio and ROI ratio separately and Jordanian insurance public companies share prices. Their study was based on the empirical evidence. Kabajeh, Nu'aimat \& Dahmash (2012) concluded that there was no relationship between the ROE ratio and Jordanian insurance public companies market share prices.

\section{Methodology of the Study}

The study was anchored on pragmatism philosophy because it involved objective testing of empirical hypotheses that were formulated as predictions of the observed phenomena. The study used a cross sectional survey which was considered to be appropriate for its purpose, scope, researcher involvement and period of time the data was collected such as nature of the data and type of analysis. A correlation research design was also considered because this study involved quantitative and testing of the hypotheses. The study target population was drawn from sixty four (64) public companies trading in NSE in Kenya (NSE Handbook, 2016). The target population was 256 senior managers and the period was for five years from 2013 to 2017 as at 30th June, 2017 (NSE Handbook, 2016). Stratified random sampling procedure was used since the population was subdivided into groups or strata. The 64 companies in NSE in Kenya were categorized as follows: six were in agricultural sector, two were in automobiles and accessories, ten were in banking sector, thirteen were in commercial and services, five were both in construction and allied sector together with energy and petroleum, six were in insurance, five were in investment, one was in investment services, 
nine were in manufacturing and allied, one was in telecommunications and technology and lastly, one was in real estate investment trust (NSE Handbook, 2015). A sample of 38 companies listed in NSE formed the unit of analysis and a purposive sample that included; chief executive officers, heads of human resources, finance and marketing who participated in the study totaling to 152 senior managers. Mugenda \& Mugenda (2003) posit that sampling involves selection of a number of study units from a defined population. Mugenda \& Mugenda (2003) noted that a sample size of $10 \%$ to $30 \%$ was a good representation of the target population and hence, adequate for analysis for this study because it fulfilled the requirements of efficiency, representation, reliability and flexibility. The sample size was determined based on precision rate and confidence level. A desired minimum precision rate of $+5 \%$ and a confidence level of $95 \%$ was used (Kothari, 2009). Cochran's formula of 'return sample size method' for categorical data as propounded by Mugenda and Mugenda (2003). The formula was effective in determining the sample size by Kinyua (2016). The number of companies sampled was $38 * 4$ number of Senior Managers $=152$ Senior Managers being the final sample size estimate was adjusted as recommended by Mugenda and Mugenda (2003). The research instrument for the collection of primary data was a semi-structured questionnaire. The study piloted the instruments to 15 senior managers namely; 3-Chief Executive Officers, 4-heads of human resources, 4-heads of finance and 4-heads of marketing from a sample of 152 respondents which is $10 \%$ of 152 equals to 15 senior managers. The split-half reliability test showed a Cronbach's Alpha of $r=0.791$, this was above 0.7 , hence the tool was reliable. The recommended value was 0.7 which this study used as cut-off reliabilities. Performance of companies alpha coefficient was 0.832. Data analysis was done through descriptive and inferential statistics such as correlation, hypothesis testing, and regression model.

\section{Research Finding and Discussions \\ Organizational Management and Performance of Companies listed in NSE}

The fourth objective of the study sought to assess the effect of organizational management on performance of companies listed in NSE in a Likert scale of 1-5 where; 1-Strongly disagree,2disagree,3-neutral,4-agree and 5-strongly agree. The results are presented in table 1. 
INTERNATIONAL JOURNAL OF ACADEMIC RESEARCH IN BUSINESS AND SOCIAL SCIENCES

Vol. 10, No. 2, Feb, 2020, E-ISSN: 2222-6990 @ 2020 HRMARS

Table 1: Descriptive Statistics for Organizational Management

\begin{tabular}{|c|c|c|c|c|c|c|c|}
\hline Statements & S.D & D & $\mathbf{N}$ & A & SA & $\overline{\mathrm{x}}$ & SD \\
\hline \multicolumn{8}{|l|}{ Planning Process } \\
\hline $\begin{array}{l}\text { Managers should be able to } \\
\text { evaluate all potential tasks at } \\
\text { the same time picking the } \\
\text { most important ones. }\end{array}$ & $0.6 \%(1)$ & $2.3 \%(3)$ & $12.6 \%(15)$ & $44.0 \%(53)$ & $40.6 \%(48)$ & 4.22 & 0.794 \\
\hline $\begin{array}{l}\text { Managers do not explain the } \\
\text { tasks to be undertaken } \\
\text { appropriately to employees } \\
\text { when planning. }\end{array}$ & $4.6 \%(6)$ & $7.4 \%(9)$ & $22.3 \%(27)$ & $38.3 \%(46)$ & $26.9 \%(32)$ & 3.76 & 1.072 \\
\hline $\begin{array}{l}\text { Planning is useful for } \\
\text { developing organization's } \\
\text { strategic plan. }\end{array}$ & $1.7 \%(2)$ & $9.7 \%(12)$ & $25.1 \%(30)$ & $38.3 \%(46)$ & $25.1 \%(30)$ & 3.75 & 0.995 \\
\hline \multicolumn{8}{|l|}{ Process } \\
\hline $\begin{array}{l}\text { Communication channels are } \\
\text { well established among staff } \\
\text { in our organization. }\end{array}$ & $2.3 \%(3)$ & $3.4 \%(4)$ & $16.6 \%(20)$ & $50.3 \%(60)$ & $27.4 \%(33)$ & 3.97 & 0.887 \\
\hline $\begin{array}{l}\text { Coordination does not } \\
\text { correct }\end{array}$ & $2.3 \%(3)$ & $14.4 \%(17)$ & $26.4 \%(32)$ & $36.2 \%(43)$ & $20.7 \%(25)$ & 3.59 & 1.043 \\
\hline $\begin{array}{l}\text { executor's actions which do } \\
\text { not comply with the plan of } \\
\text { the organization. }\end{array}$ & & & & & & & \\
\hline $\begin{array}{l}\text { Coordination combines the } \\
\text { organizations goals and } \\
\text { specialization in respect of } \\
\text { division of labor and } \\
\text { formation of chain of } \\
\text { commands }\end{array}$ & $13.1 \%(16)$ & $31.4 \%(38)$ & $24.6 \%(30)$ & $17.7 \%(21)$ & $12.7 \%(15)$ & 4.22 & 0.794 \\
\hline \multicolumn{8}{|l|}{ Motivation of Staff } \\
\hline $\begin{array}{l}\text { Money motivates employees } \\
\text { towards higher performance. }\end{array}$ & $1.7 \%(2)$ & $7.4 \%(9)$ & $12.0 \%(14)$ & $58.9 \%(71)$ & $20.0 \%(24)$ & 3.76 & 1.072 \\
\hline $\begin{array}{l}\text { Incentives such as security, } \\
\text { good working condition, } \\
\text { opportunity for growth and } \\
\text { development creates } \\
\text { redundancy of employees. }\end{array}$ & $1.7 \%(2)$ & $4.0 \%(5)$ & $12.0 \%(14)$ & $42.9 \%(51)$ & $39.6 \%(48)$ & 3.75 & 0.995 \\
\hline $\begin{array}{l}\text { Our organization uses } \\
\text { rewards to contribute to } \\
\text { firm's effectiveness by } \\
\text { influencing individuals or } \\
\text { group behavior. } \\
\text { Controlling of Resources }\end{array}$ & $1.7 \%(2)$ & $9.1 \%(11)$ & $16.0 \%(19)$ & $36.6(44)$ & $36.6 \%(44)$ & 3.97 & 0.887 \\
\hline $\begin{array}{l}\text { We set performance targets } \\
\text { in our organization to be } \\
\text { achieved by employees. }\end{array}$ & $2.3 \%(3)$ & $5.7 \%(7)$ & $15.4 \%(18)$ & $44.0 \%(53)$ & $32.6 \%(39)$ & 3.59 & 1.043 \\
\hline $\begin{array}{l}\text { Resources such as financial, } \\
\text { human, material and others } \\
\text { are not utilized prudently in } \\
\text { our organization. }\end{array}$ & $1.7 \%(2)$ & $3.4 \%(4)$ & $18.3 \%(22)$ & $38.3 \%(46)$ & $38.3 \%(46)$ & 2.86 & 1.238 \\
\hline $\begin{array}{l}\text { Every divisional head is in } \\
\text { charge of the budget in our } \\
\text { organization. }\end{array}$ & $14.3 \%(17)$ & $20.6 \%(25)$ & $24.6 \%(30)$ & $24.0 \%(29)$ & $16.6 \%(20)$ & 3.88 & 0.873 \\
\hline Composite Mean & & & & & & 3.84 & 0.970 \\
\hline
\end{tabular}


INTERNATIONAL JOURNAL OF ACADEMIC RESEARCH IN BUSINESS AND SOCIAL SCIENCES Vol. 10, No. 2, Feb, 2020, E-ISSN: 2222-6990 @ 2020 HRMARS

Table 1 findings on whether the managers should be able to evaluate all potential tasks at the same time picking the most important ones. $0.6 \%(1)$ strongly disagreed, $2.3 \%(3)$ disagreed $12.6 \%(15)$ were neutral, $44 \%(53)$ agreed, $40.6 \%(48)$ strongly agreed. Average score rate was 4.22 out of 5 with standard deviation of 0.794 higher than the composite mean of 3.84 and overall standard deviation of 0.970 was higher. This indicates that manager's evaluated all potential tasks at the same time picking the most important ones and this positively affect performance of companies listed in NSE.

In regard to know the extent to which managers do not explain the tasks to be undertaken appropriately to employees when planning,4.6\%(6) strongly disagreed,7.4\%(9) disagreed ,while $22.3 \%(27)$ were neutral, 38.3\%(46) agreed, $26.9 \%(32)$ strongly agreed. Average score rate was 3.76 out of 5 with standard deviation of 1.072 below the composite mean of 3.84 and overall standard deviation of 0.970 was lower. This indicates that managers do not explain the tasks to be undertaken appropriately to employees when planning which negatively affect performance of companies listed in NSE.

On whether planning was useful for developing organization's strategic plan was also rated as follows: $1.7 \%(2)$ strongly disagreed, 9.7\%(12) disagreed, $25.1 \%(30)$ were neutral, 38.3\%(46) agreed, $25.1 \%(30)$ strongly agreed. Average score rate was 3.75 out of 5 with standard deviation of 0.995 which was below the composite mean of 3.84 and overall standard deviation of 0.970 was lower. This indicates that planning process was useful for developing organization's strategic plan which negatively affect performance of companies listed in NSE.

On whether communication channels are well established among staff in our organization; $2.3 \%(3)$ strongly disagreed, $3.4 \%(4)$ disagreed, while $16.6 \%(20)$ were neutral, 50.3\%(60) agreed, $27.4 \%(33)$ strongly agreed. Average score rate was 3.97 out of 5 with standard deviation of 0.887 which was above the composite mean of 3.84 and overall standard deviation of 0.970 was higher. This indicates that communication channels positively affect performance of companies listed in NSE.

Concerning whether coordination does not correct executor's actions which do not comply with the plan of the organization the finding were as follows: $2.3 \%(3)$ strongly agreed, $14.4 \%(17)$ disagreed, $26.4 \%(32)$ were neutral, $36.2 \%(43)$ disagreed and $20.7 \%(25)$ strongly disagreed. Average score rate was 3.59 out of 5 with standard deviation of 1.043 which was below the composite mean of 3.84 and standard deviation of 0.970 was lower. This indicates that coordination of executor's actions negatively affect performance of companies listed in NSE.

On whether coordination combines the organizations goals and specialization in respect of division of labor and formation of chain of commands, the results were as follow: $13.1 \%(16)$ strongly disagreed, $31.4 \%$ ( 38) disagreed. $24.6 \%(30)$ were neutral $17.7 \%(21)$ agreed, $12.7 \%(15)$ strongly agreed. Average score rate was 4.22 out of 5 with standard deviation of 0.794 which was over and above the composite mean of 3.84 and overall standard deviation of 0.970 was higher. This indicates that organization goals and specialization of managers positively affect performance of companies listed in NSE. 
INTERNATIONAL JOURNAL OF ACADEMIC RESEARCH IN BUSINESS AND SOCIAL SCIENCES Vol. 10, No. 2, Feb, 2020, E-ISSN: 2222-6990 @ 2020 HRMARS

On whether money motivates employees towards higher performance, $1.7 \%(2)$ strongly disagreed, $7.4 \%$ (9) disagreed, while $12.0 \%$ ( 14) were neutral, $58.9 \%(71)$ agreed, $20 \%(24)$ strongly agreed. Average score rate was 3.76 out of 5 with standard deviation of 1.072 which was below the composite mean of 3.84 and overall standard deviation of 0.970 was lower. This indicates that money motivates employees and negatively affect performance of companies listed in NSE.

On whether incentives such as security, good working condition, opportunity for growth and development creates redundancy of employees;1.7\%(2) strongly disagreed, $4.0 \%(5)$ disagreed, while $12.0 \%(14)$ were neutral, $42.9 \%(51)$ agreed, 39.4\%(48) strongly agreed. Average score rate was 3.75 out of 5 with standard deviation of 0.995 which was below the composite mean of 3.84 and overall standard deviation of 0.970 was lower. This indicates that incentives such as security, good working condition, opportunity for growth and development negatively affect performance of companies listed in NSE.

On whether our organization uses rewards to contribute to firm's effectiveness by influencing individuals or group behavior,1.7\%(2) strongly disagreed, $9.1 \%(11)$ disagreed, while 16.0\%(19) were neutral, $36.6 \%(44)$ agreed, $36.6 \%(44)$ strongly agreed. Average score rate was 3.97 out of 5 with standard deviation of 0.887 which was higher than the composite mean of 3.84 and overall standard deviation of 0.970 was higher. This indicates that rewards to individuals or group positively affect performance of companies listed in NSE.

On whether we set performance targets in our organization to be achieved by employees, $2.3 \%(3)$ strongly disagreed, $5.7 \%(7)$ disagreed, while $15.4 \%(18)$ were neutral, $44.0 \%(53)$ agreed, $32.6 \%(39)$ strongly agreed. Average score rate was 3.59 out of 5 with standard deviation of 1.043 which was below the composite mean of 3.84 and overall standard deviation of 0.970 was lower. This indicates that performance targets review determines how the employees were working and negatively affect performance of companies listed in NSE.

On whether Resources such as financial, human, material and others are not utilized prudently in our in our organization; $1.7 \%(2)$ strongly disagreed, $3.4 \%(4)$ disagreed, while $18.3 \%(22)$ were neutral, $38.3 \%(46)$ agreed, $38.3 \%(46)$ strongly agreed. Average score rate was 2.86 out of 5 with standard deviation of 1.238 which was below the composite mean of 3.84 and overall standard deviation of 0.970 was lower. This indicates that availability of resources negatively affect performance of companies listed in NSE.

On whether every divisional head is in charge of the budget in our organization, $14.3 \%(17)$ strongly disagreed, $20.6 \%(25)$ disagreed, while $24.6 \%(30)$ were neutral, $24.0 \%(29)$ agreed, $16.6 \%(20)$ strongly agreed. Average score rate was 3.88 out of 5 with standard deviation of 0.873 which was below the composite mean of 3.84 and overall standard deviation of 0.970 was higher. This indicates that all divisional heads were budget holders who ensured that operations/processes of the companies were running smoothly which positively affect performance of companies listed in NSE. The summary is presented in Table 2. 
INTERNATIONAL JOURNAL OF ACADEMIC RESEARCH IN BUSINESS AND SOCIAL SCIENCES Vol. 10, No. 2, Feb, 2020, E-ISSN: 2222-6990 @ 2020 HRMARS

Table 2: Summary of Descriptive Statistics for Organizational Management

\begin{tabular}{lccc}
\hline $\begin{array}{l}\text { Organizational } \\
\text { Management }\end{array}$ & Mean & Std. Deviation & Analysis N \\
\hline Planning Process & 3.910 & 0.954 & 120 \\
Coordination of Change & 3.806 & 2.191 & 120 \\
Process & 3.780 & 1.052 & 120 \\
Motivation of Staff & 3.403 & 1.050 & 120 \\
Controlling of Resources & & & \\
\hline
\end{tabular}

Table 2 indicate that, the average score for planning process, coordination of change process, motivation of staff and controlling of resources were 3.910, 3.06, 3.780 and 3,403 respectively out of 5 possible rates. On the other hand, standard deviation indicates that the dispersion was very little. These findings, show that Standard deviation suggest that planning process, coordination of change process, motivation of staff and controlling had an effect on Performance of Companies listed in Nairobi Securities Exchange.

These results are in harmony with the findings by Muogbo (2013) that strategic management adoption had an effect on employee's performance by increasing organizational productivity and enhancing structural development. The results also agree with the findings by Kehinde (2012) which indicate that there was a positive impact between talent management and organizational performance of both multinational and national firms. The results further concur with the findings by Aremu and Oyinloye (2014) that strategic management affects organizational performance and that no matter how well-structured and organized a plan may be, if not implemented then businesses would fail.

This result confirms that organizational management is critical in planning process and helpful in developing the organization's strategic plan, setting objectives, managing resources and developing the human and financial assets that are utilized prudently by controlling them and eliminating wastage. The results further show that coordination of change process will combine the organizations and specialization in divisions of labor and formation of chain of command. The findings also confirms that motivation of staff like incentives such as security, good working condition, opportunity for growth and development contributes to good performance of companies. The findings also were in approval of the Open Systems Theory propounded by Bertalanffy (1972) in this study.

\section{Correlation Analysis for Organizational Management and Performance of Companies} Linearity of variables was tested using correlation coefficients as suggested by Cohen, West and Aiken (2003). To establish whether there was a linear relationship, the study adopted the Pearson moment's correlation coefficients. The results are presented in table 3. 
INTERNATIONAL JOURNAL OF ACADEMIC RESEARCH IN BUSINESS AND SOCIAL SCIENCES Vol. 10, No. 2, Feb, 2020, E-ISSN: 2222-6990 @ 2020 HRMARS

Table 3: Correlation Coefficients for Organizational Management and Performance of Companies

\begin{tabular}{cccc}
\hline Variable & & $\begin{array}{c}\text { Performan } \\
\text { ce of } \\
\text { Companies }\end{array}$ & $\begin{array}{c}\text { Organizational } \\
\text { Management }\end{array}$ \\
\hline Performance of & Pearson Correlation & 1 & $.634^{* *}$ \\
Companies & Sig. (2-tailed) & $\mathrm{N}$ & 143 \\
& Pearson Correlation & $.634^{* *}$ & 143 \\
Organizational & Sig. (2-tailed) & .000 & 1 \\
Management & $\mathrm{N}$ & 143 & 143 \\
& & & \\
\hline
\end{tabular}

**. Correlation is significant at the 0.01 level (2-tailed).

Table 3 indicates that there was a significant moderate positive correlation between organizational management and performance of companies $r=0.634, p<0.001, C L=95 \%$. This implies that there was a linear positive relationship. Thus an increase in organizational management would result in a linear increase in performance of companies. This is presented in Figure 2.

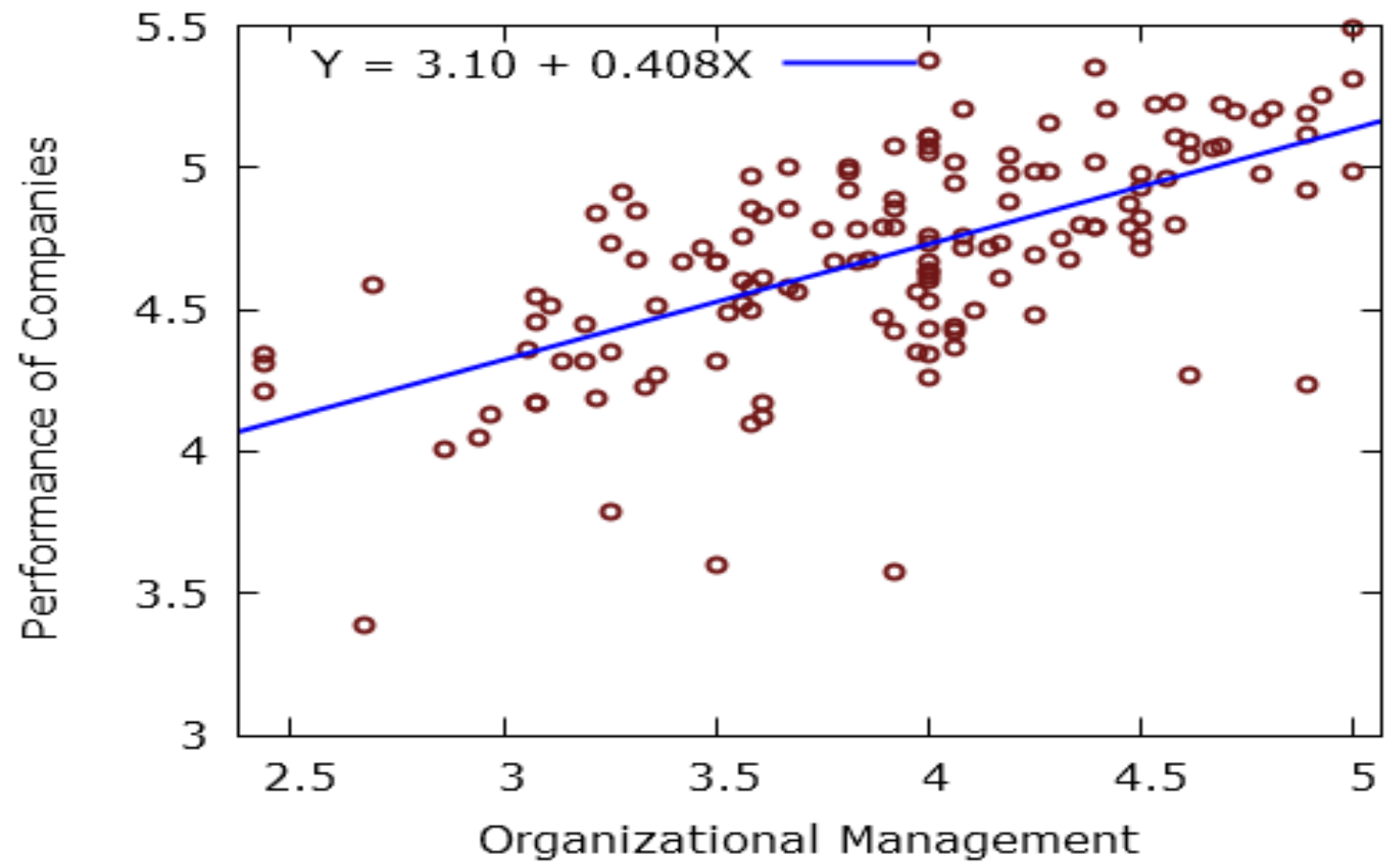

Figure 2: Scatter plot between Performance of Companies and Organizational Management

\section{Hypothesis testing for Organizational Management and Performance of Companies}

The study analyzed the null hypothesis that organizational management does not significantly affect performance of companies listed in NSE. The coefficient of regression equation between organizational management and performance of companies can be expressed as; $Y=\beta_{0}+\beta_{1} X_{3}$ which results to $Y=3.1+0.408 X_{4}$ when there is no moderator and $Y=-0.297+0.973 X_{4} * Z$ with moderator from the coefficient. The results are presented in Table 4. 
INTERNATIONAL JOURNAL OF ACADEMIC RESEARCH IN BUSINESS AND SOCIAL SCIENCES

Vol. 10, No. 2, Feb, 2020, E-ISSN: 2222-6990 @ 2020 HRMARS

Table 4: Regression Coefficients for Organizational Management

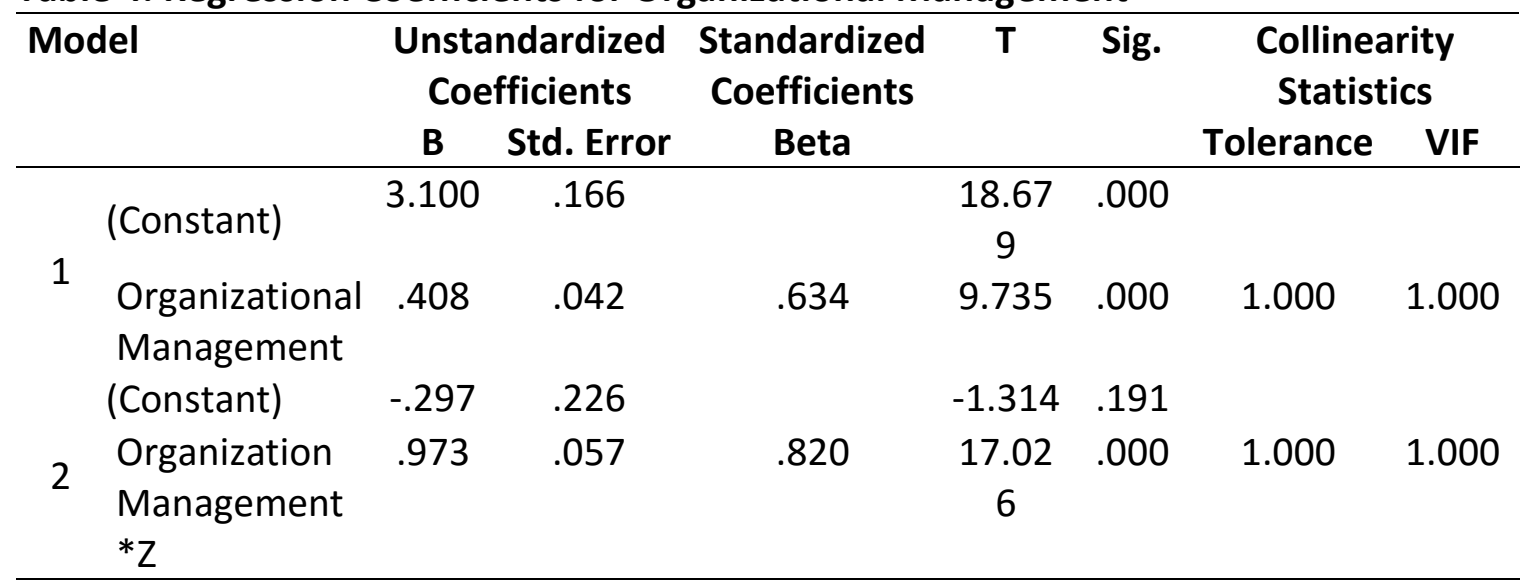

a. Dependent Variable: Performance of Companies (Y)

Table 4 show that $p$-values with and without the moderating variable (Technology) are 0.000 which were less than 0.05 . This implies that there was a positive significant relationship between organizational management and performance of companies. The R- square value of 0.402 was recorded indicating that $40.2 \%$ of performance of companies was explained by the organizational management without moderator.

On the other hand, R-square value of 0.973 was recorded indicating that $97.3 \%$ of performance of companies was explained by the organizational management with moderator. From the analysis it was therefore concluded that, the null hypothesis be rejected and the alternative be accepted; that there was a positive significant relationship between organizational management and Performance of Companies.

\section{ANOVA for Organizational Management}

The results of ANOVA for organizational management are presented in Table 5.

Table 5: ANOVA for Organizational Management

\begin{tabular}{|c|c|c|c|c|c|c|}
\hline Mode & & $\begin{array}{l}\text { Sum of } \\
\text { Squares }\end{array}$ & Df & Mean Square & $F$ & Sig. \\
\hline \multirow{3}{*}{1} & Regression & 7.917 & 1 & 7.917 & 94.770 & $.000^{b}$ \\
\hline & Residual & 11.779 & 141 & .084 & & \\
\hline & Total & 19.697 & 142 & & & \\
\hline \multirow{3}{*}{2} & Regression & 45.039 & 1 & 45.039 & 289.881 & $.000^{\mathrm{b}}$ \\
\hline & Residual & 21.907 & 141 & .155 & & \\
\hline & Total & 66.947 & 142 & & & \\
\hline
\end{tabular}

a. Dependent Variable: Performance of Companies (Y)

b. Model 1 and 2 Predictors: (Constant), $X_{4}$ 
INTERNATIONAL JOURNAL OF ACADEMIC RESEARCH IN BUSINESS AND SOCIAL SCIENCES Vol. 10, No. 2, Feb, 2020, E-ISSN: 2222-6990 @ 2020 HRMARS

Table 5 indicate that the overall model with and without moderator was significant, that is, the independent variable (organizational management) was a good joint explanatory for performance of companies with F-value of 94.770 and 289.881 model 1 and model 2 respectively. P- Values were $0.001<0.05$ also indicates that the models are fit.

\section{Performance of Companies Listed in NSE}

This section concerns descriptive analysis of the dependent variable (Performance of Companies). The respondents were asked to state their level of agreement on the following items for Performance of Companies listed in Nairobi Securities Exchange. In a Likert scale of 1-5 where; 1-Strangly disagree, 2-Disagree, 3-Neutral, 4-Agree and 5-Strongly Agree. The results are presented in table 6.

Table 6: Descriptive Statistics for Performance of Companies

\begin{tabular}{|c|c|c|c|c|c|c|c|}
\hline Statement & S.D & D & $\mathbf{N}$ & A & S. A & Mean & $\begin{array}{l}\text { Std. } \\
\text { Dev }\end{array}$ \\
\hline Net Profit & $0.6 \%$ & $1.7 \%$ & $6.9 \%$ & $41.1 \%$ & $49.7 \%$ & 4.38 & $\begin{array}{l}0.73 \\
9\end{array}$ \\
\hline Dividend Per Share & $\begin{array}{l}0.6 \\
\%\end{array}$ & $\begin{array}{l}1.1 \\
\%\end{array}$ & $6.9 \%$ & $37.1 \%$ & $54.3 \%$ & 4.43 & $\begin{array}{l}0.72 \\
3\end{array}$ \\
\hline Return on Investment & $\begin{array}{l}1.1 \\
\%\end{array}$ & $\begin{array}{l}2.9 \\
\%\end{array}$ & $13.7 \%$ & $40.6 \%$ & $41.7 \%$ & 4.19 & $\begin{array}{l}0.86 \\
0\end{array}$ \\
\hline Quality products and Services & $\begin{array}{l}0.6 \\
\%\end{array}$ & $\begin{array}{l}3.4 \\
\%\end{array}$ & $8.6 \%$ & $42.3 \%$ & $45.1 \%$ & 4.28 & $\begin{array}{l}0.80 \\
7\end{array}$ \\
\hline Customer Satisfaction & $\begin{array}{l}0.0 \\
\%\end{array}$ & $\begin{array}{l}2.9 \\
\%\end{array}$ & $24.0 \%$ & $35.4 \%$ & $37.7 \%$ & 4.08 & $\begin{array}{l}0.85 \\
4\end{array}$ \\
\hline New products & $\begin{array}{l}0.0 \\
\% \\
\end{array}$ & $\begin{array}{l}4.6 \\
\% \\
\end{array}$ & $12.6 \%$ & $45.1 \%$ & $37.7 \%$ & 4.16 & $\begin{array}{l}0.81 \\
5 \\
\end{array}$ \\
\hline Composite Mean & & & & & & 4.20 & $\begin{array}{l}0.83 \\
2\end{array}$ \\
\hline
\end{tabular}

From Table 6 findings were on whether the financial performance of the organization is pegged on the Net Profit; $0.6 \%$ of the respondents strongly disagreed, $1.7 \%$ disagreed, while $6.9 \%$ were neutral, $41.1 \%$ of the respondents agreed and $49.7 \%$ strongly agreed. Average score rate was 4.38 out of 5 with standard deviation of 0.739 was higher than the composite mean of 4.20 and standard deviation of 0.832. This suggest that majority of the companies listed in Nairobi Securities Exchange measure their performance based on net profit which is confirmed by composite mean of 4.20 and standard deviation of 0.832 which is lower.

On whether the companies listed in Nairobi Securities Exchange measure their performance based on Return on Investment, $1.1 \%$ strongly disagreed, $2.9 \%$ disagreed, while $13.7 \%$ were neutral, $40.6 \%$ of the respondents agreed and $41.7 \%$ strongly agreed. An average score rate of 4.19 was recorded with standard deviation of 0.86 was lower than the composite mean of 4.20 and standard deviation 
INTERNATIONAL JOURNAL OF ACADEMIC RESEARCH IN BUSINESS AND SOCIAL SCIENCES Vol. 10, No. 2, Feb, 2020, E-ISSN: 2222-6990 @ 2020 HRMARS

of 0.832. This indicates that majority of the companies listed in Nairobi Securities Exchange measure their performance based on return on investment.

On whether the companies listed in Nairobi Securities Exchange measure their performance based on dividend per share, majority of the respondents $0.6 \%$ strongly disagreed, $1.1 \%$ disagreed, while $6.9 \%$ were neutral, $37.1 \%$ agreed and strongly agreed at $54.3 \%$. This also indicates that majority of the companies listed in Nairobi Securities Exchange measure their performance based on dividend per share with an overall mean rate of 4.43 and standard deviation 0.723 .

The Respondents were asked whether the non-financial performance of the organization is pegged on the Quality products produced and Services provided, $0.6 \%$ strongly disagreed $3.4 \%$ disagreed, while $8.6 \%$ were neutral, $42.3 \%$ of respondents agreed and $45.1 \%$ strongly agreed. Average scale of 4.28 out possible 5 and standard deviation of 0.80 was recorded with a composite mean of 4.20 and standard deviation of 0.832 . This means that quality products produced and Services provided affect financial performance of companies listed in Nairobi Securities Exchange.

To find out whether performance of companies listed in Nairobi Securities Exchange are normally based on Customer Satisfaction, $0.0 \%$ strongly disagreed, $2.9 \%$ disagreed, while $24.0 \%$ were neutral, majority of the respondents at $35.4 \%$ agreed and $37.7 \%$ strongly agreed. Average scale of 4.08 out possible 5 and standard deviation of 0.854 was below the composite mean of 4.20 and standard deviation of 0.832 . This means that customer satisfaction affect financial performance of companies listed in Nairobi Securities Exchange.

To find out whether performance of companies listed in Nairobi Securities Exchange are normally based on New Products, $0.0 \%$ strongly disagreed, $4.6 \%$ disagreed, while $12.6 \%$ were neutral, majority of the respondents at $45.1 \%$ agreed and $37.7 \%$ strongly agreed. Mean score of 4.16 out of 5 and standard deviation of 0.815 was below the composite mean of 4.20 and standard deviation of 0.832 . This means that new products produced affect financial performance of companies listed in Nairobi Securities Exchange. In general, the respondents were in agreement with all the items listed under Performance of Companies.

\section{Discussions and Findings}

These results are in harmony with the findings by Muogbo (2013) that strategic management adoption had an effect on employee's performance by increasing organizational productivity and enhancing structural development. The results also agree with the findings by Kehinde (2012) which indicate that there was a positive impact between talent management and organizational performance of both multinational and national firms. The results further concur with the findings by Aremu and Oyinloye (2014) that strategic management affects organizational performance and that no matter how well-structured and organized a plan may be, if not implemented then businesses would fail. These result confirms that organizational management is critical in planning process and helpful in developing the organization's strategic plan, setting objectives, managing resources and developing the human and financial assets that are utilized prudently by controlling them and eliminating wastage. 
The results further show that coordination of change process will combine the organizations and specialization in divisions of labor and formation of chain of command. The findings also confirms that motivation of staff like incentives such as security, good working condition, opportunity for growth and development contributes to good performance of companies. The findings also were in approval of the Open Systems Theory propounded by Bertalanffy (1972) in this study. These results are in harmony with the findings by Fauzi, Svensson and Rahman (2010) that the concept of triple bottom line as sustainable corporate performance should consist of three measurement elements namely; financial, social and environmental and the content of each of these measurement elements may vary across contexts and over time. The results confirm that listed companies in Nairobi Securities Exchange in Kenya have well documented financial reports online in their websites and that of NSE website that determines the threshold set by Capital Markets Authority (CMA), a regulator and shows whether the listed companies have complied according to the laid down rules and regulations.

\section{Conclusion}

The study sought to assess the effect of organizational management on performance of companies listed in NSE. It was concluded that there was a statistical effect of organizational management on performance of companies. The null hypothesis was rejected and alternative hypothesis was accepted. Aremu \& Oyinloye (2014) findings showed that a well-structured and organized plan, if not implemented well in the business may collapse.

\section{Significance of the Study}

Capital Markets Authority and Nairobi Securities Exchange policy makers in Kenya will benefit from the findings of this study in formulation and implementation of policies related to change management and how they can regulate trading in NSE in Kenya. The Government will also find the study useful in making policies, rules and regulations that governs trading in NSE to protect investors and support companies financially through bail out when suspended from trading in NSE in order to grow the economy. Firms and individuals (investors), the findings will enable them understand the challenges in implementing change management and the need to involve all stakeholders to participate as this will bring a sense of ownership and responsibility. In addition, scholars and researchers will find the study findings useful for current and further research in change management and performance of companies listed in NSE in Kenya.

\section{Recommendation}

In organizational management, managers should get recent and relevant information that exists as this should enable them make decisions and know how to get cooperation from subordinates, peers, superiors and people whom they have no formal authority on when implementing change management. This will ensure that wastage of resources is also minimized. Implementation of change management should involve all stakeholders to ensure that there is no resistance among staff members because everybody will be responsible for decision making process and own up the process. Management should ensure that policies and procedures are adequate to guide the change management through the human resources department so that an environment of awareness is created. This will go a long way to mitigate staff stress and unrest early enough. 
INTERNATIONAL JOURNAL OF ACADEMIC RESEARCH IN BUSINESS AND SOCIAL SCIENCES

Vol. 10, No. 2, Feb, 2020, E-ISSN: 2222-6990 @ 2020 HRMARS

\section{Contribution of the Study to the Body of Knowledge, Theory and Practice}

The methodology the study adopted was questionnaire. The research gap has been addressed by administering questionnaires to CEO's, head of divisions in human resources, finance and marketing of companies then conducting quantitative analysis. The study established that performance of companies listed in NSE in Kenya was affected by organizational management. The study has also established that there was a significant positive effect of organizational management, in the context of change management and performance of companies listed in NSE in Kenya.

\section{References}

Abbah, M. T. (2014). Employee Motivation: The Key to Effective Organizational Management in Nigeria. IOSR Journal of Business and Management, 16 (4), 01-08.

Abiro, M. A. (2013). Effect of Employee Motivation on Organizational Performance. Acta de Gerencia Ciencia, 1(3), 17-27.

Ali, F., \& Recep, B. (2012). Yes, Dividends are disappearing: Worldwide Evidence. Journal of Banking and Finance, $36(3), 662-667$.

Adelegan, O. J. (2008). Can a Regional Approach Accelerate Stock Market Development? Empirical Evidence from Sub-Saharan Africa. IMF Working Paper 08/281, Washington: International Monitory Fund.

Aremu, M. A., \& Oyinloye, O. O. (2014). Relationship between Strategic Management and Firm's Performance in Nigerian Banking Industry. Kuwait Chapter of Arabian Journal of Business and Management Review, 4(3), 28-41.

Bandura, A. (1986). Social Foundations of Thought and Action: A Social Cognitive Theory. Englewood Cliffs, NJ: Prentice Hall.

Basted, M. N. (2004). Open Systems Theory. Michigan: University of Michigan.

Basu, K. (1993). Lectures in Industrial Organization Theory, Oxford: Basil Blackwell.

Bain, J. S. (1968). Barriers to New Competition, Cambridge, Mass.: Harvard University Press.

Barney, J. B. (2001). Is the Resource-Based "View" a Useful Perspective for Strategic

Management Research? Academy of Management Review. 26(1), 22-40.

Bertalanffy, L. V. (1968). General System Theory: Foundations, Development,Applications. New York: G.Braziller.

Beshtawi, M., \& Jaaron, A. (2014). Change Management in Telecommunications Sector: Managerial Framework. Review of Contemporary Business Research, 3(1), 127-141.

Boohene, R., and Williams, A.A. (2012). Resistance to Organizational Change: A Case Study of Oti Yeboah Complex Limited. International Business and Management, 4(1)135-145.

Burnes, B. (2004). Kurt Lewin and the Planned Approach to Change: Are Appraisal. Journal of Management Studies, 41(2), 917-1001.

Burnes, B. (2004). Kurt Lewis and Complexity Theories: back to the future? Journal of Change Management, 4(4), 309-325.

Bruce, M. (2010). Understanding Organizations: The Dominance of Open Systems Theory. International Journal of Organizational Behavior, 4(1), 256-261.

CMA. (2002). The Capital Markets (Licensing Requirements) (General) Regulations. Nairobi: Capital Markets Authority. 
INTERNATIONAL JOURNAL OF ACADEMIC RESEARCH IN BUSINESS AND SOCIAL SCIENCES

Vol. 10, No. 2, Feb, 2020, E-ISSN: 2222-6990 @ 2020 HRMARS

D’Ortenzio, C. (2012). Understanding Change and Change Management Processes: A Case Study. Unpublished Thesis: University of Canberra.

Fayol, H. (1949). General and Industrial Management. London: Sir Isaac Pitman \& Sons.

Fauzi, H., Svensson, G., \& Rahman, A.A. (2010). Triple Bottom Line as Sustainable

Corporate Performance: A Preposition for the Future. Sustainability, 2(5), 1345-1360.

Fishbein, M., Bandura, A., Triandis, H. C., Kanfer, F. H., Becker, M. H., \& Middlestadt, S. E. (1992). Factors Influencing Behavior and Behavior Change. Bethesda, MD: National Institute of Mental Health.

Freeman, R. E., (1984). Strategic Management: A stakeholder Approach. Boston, MA: Pitman.

Gavrea, C., Kies L., \& Stegerean, R. (2011). Determinants of the Organizational Performance: The Case of Romania. Management and Marketing Challenges for the Knowledge Society, 6(2), 285-350.

Gaye, D. (2017). World Bank's Kenya Economic Update: Kenya's Economic Outlook to Dip In 2017.

Gitahi, A. W., \& K'Obonyo, P. O. (2018).The Relationship between Organizational Resources and Firm Performance of Companies Listed on the Nairobi Securities Exchange. International Journal of Economics, Commerce and Management, VI (5), 540-555.

Ghosh, S. \& Mukhertjee, S. (2006). Measurement of Corporate Performance through Balance Scorecard. Overview Vidyasagar University Journal of Commerce, 11(1), 64-69.

Hanna, D. (1988). Designing Organizations for High Performance. New York: Addison-Wesley Publishing.

Irungu, S. M. (2007). The Effects of Top Management Teams on the Performance of Publicly Quoted Companies in Kenya. Unpublished Thesis. Nairobi: University of Nairobi.

Kamugisha, S. (2013). The Effects of Change Management in an Organization: A Case Study of the National University of Rwanda (NUR). Wyno Journal of Management and Business Studies, 11(1), 1-18.

Kabajeh, M. A. M., \& Dahmash, F. N. (2012). The Relationship between the ROA, ROE and ROI Ratios with Jordanian Insurance Public Companies Market Share Prices. International Journal of Humanities and Social Science, 2(11), 115-120.

Kabiru, F. C., Theuri, M., \& Misiko, A. (2018). The Influence of Planning on The Organizational Performance of Agricultural State-Owned Corporations in Kenya. International Academic Journal of Human Resource and Business Administration, 3(1), 68-80.

Kehinde, J. S. (2012). Talent Management: Effect on Organizational Performance. Journal of Management Research, 4(2), 178-186.

Kritsonis, A. (2004). Comparison of Change Theories. International Journal of Scholarly Academic Intellectual Diversity, 8(1), 1-7.

Kothari, C. R. (2009). Research Methodology: Methods and Techniques. New Delhi: New Age International.

Kinyua, J. K. (2016). Effect of Internal Control Systems on Financial Performance of Companies Quoted in the Nairobi Securities Exchange. Unpublished Thesis. Nairobi: Jomo Kenyatta University of Agriculture and Technology.

Lewin, K. (1947). Frontiers in Group Dynamics in: D. Cartwright (Ed.) (1952). Field Theory in the Social Science. London: Science Paperbacks.

Machuki, V. M., \& K'Obonyo, P. O. (2011). Organizational Strategic Behavior and Performance of 
INTERNATIONAL JOURNAL OF ACADEMIC RESEARCH IN BUSINESS AND SOCIAL SCIENCES

Vol. 10, No. 2, Feb, 2020, E-ISSN: 2222-6990 ¿ 2020 HRMARS

Publicly Quoted Companies in Kenya. Business Administration and Management, 1(7), 219232.

Machuki, V. M. (2011). External Environment-Strategy Co-Alignment, Firm-Level Institutions and Performance of Publicly Quoted Companies in Kenya. Unpublished Thesis. Nairobi: University of Nairobi.

Mugenda, O. M., \& Mugenda, A. G. (2003). Research Methods, Quantitative and Qualitative Approaches. African Centre for Technology Studies. Nairobi: Press.

McAleese, I., Creed, A., \& Zutshi, A. (2013). A Response to Critique of the Refreeze Step in Lewin's Model of Organizational Change from the Viewpoint of Organizational Behavior. International Journal of the Academy of Organizational Behavior Management, 3(4), 104-124.

Muogbo, U. S. (2013).The Impact of Strategic Management on Organizational Growth and Development Study of Selected Manufacturing Firms in Anambra State). Journal of Business and Management, 7(1), 24-32.

Naghibi, M. A., \& Baban, H. (2011). Strategic Change Management: The Challenges Faced by Organizations. Singapore: ACSIT Press.

Nurwati. (2013). Effect of Management Control to Organizational Culture, Compensation, Work Behavior and Employees Performance. (Studies in the Village Unit Cooperatives (KUD) in South East

Sulawest). Journal of Business and Management, 8(4), 40-52.

Nohria, N., \& Beer, M. (2000). Cracking the Code of Change. Harvard Business Review,1-10.

Olusanya, S. O., Awotungase, S. A., \& Ohadebere, E. C. (2012). Effective Planning and

Organizational Productivity. (A Case Study of Sterling Bank Nigeria PIc). Journal of

Humanities and Social Science, 5(5), 31-39.

Pasmore, W., \& Sherwoord, J. J. (1978). Organizations as Sociotechnical Systems, Sociological Systems. Lajolla, CA: University Associates.

Prochaska, J. O., \& DiClemente, C. C. (1983). Stages and Processes of Self-Change of Smoking: Towards an Integrative Model of Change. Journal of Consulting and Clinical Psychology, 51(3), $390-$

395. from: https://www.researchgate.net/publication/232496534_stages_of_change.

Porter, M. E. (1981). The Contributions of Industrial Organization to Strategic Management. Academy of Management Review, 6(4), 609-620.

Rezvani, S., Dekhordi, G. J., \& Shamsolahi, A. (2012). Managing Strategic Change for Organizations. International Journal of Academic Research in Economics and Management Science, 1(3), 112-122.

Santos, J. B., \& Brito, L. A. (2012). Toward a Subjective Measurement Model for Firm Performance. BAR Rio de Janeiro, 9(6), 95-117.

Song, X. (2009). Why Do Change Management Strategies Fail? Illustrations with Case Studies. Journal of Cambridge Studies, 4(1), 6-15.

Shapiro, C. (1989). The Theory of Business Strategy. RAND Journal of Economics, 20(1), 127-137.

Suresh, H. (2011). Change Management -Must for Todays Organization. Think Business Network Articles, 1-11. 
INTERNATIONAL JOURNAL OF ACADEMIC RESEARCH IN BUSINESS AND SOCIAL SCIENCES

Vol. 10, No. 2, Feb, 2020, E-ISSN: 2222-6990 @ 2020 HRMARS

Swarnalatha, C., \& Prasanna, T. S. (2013).Leveraging Employee Engagement for Competitive Advantage: HR'S Strategic Role. Global Journal of Commerce \& Management Perspective, 2(1), 1-6. Journal of Economics and Finance, 3(2), 19-22.

Taylor, F. W. (1911). The Principles of Scientific Management. New York, NY: Harper \& Brothers.

Ufartiene, L. J. (2014). Importance of Planning in Management Development Organization. Journal of Advanced Management Science, 2(3), 176-180.

Varadarajan, P. R. (1999). Strategy Content and Process Perspectives Revisited. Journal of the Academy of Marketing Science,27(1),88-100.

Vanagas, R., \& Stankevic, J. (2014). Impact of Coordination for Organization Process. Intellectual Economics, 8(2), 112-125.

Victor, P., \& Franceiss, A. (2002). 'The Five Dimensions of Change: An Integrated Approach to Strategic Organizational Change Management'. Strategic Change, 11(1), 35-42. 